\title{
Sustainable management of water resources in the Yellow River basin: the main issues and legal approaches
}

\author{
C. Zhuang, J. Xu \& G. Chen \\ Water Resources Department, \\ Changjiang River Scientific Research Institute, China
}

\begin{abstract}
The Yellow River basin, which is one of China's most important river basins, is facing serious challenges of a rapidly developing society demanding more water while previous over-exploitation and climate change mean less is becoming available. Based on reviews and analysis, developments in the legislative and administrative arrangements in the Yellow River basin, the goal of this research is to achieve integrated management of quantity and quality, surface and ground water, river and watershed. The question is how to bring about the necessary regulatory controls and behavior changes by legal instruments or by policy and administrative means, by developing a special Yellow River Law or by developing national legislative and political mechanisms and implementing appropriately to the special needs of the Yellow River basin.

Keywords: sustainable management, the Yellow River basin, the most strict water resources management.
\end{abstract}

\section{Introduction}

The Yellow River, or Huanghe, is the second longest river in China. Originating in the Bayangela Mountains in western China, the river drops a total of 4,500 m as it loops north into the Gobi Desert before turning south through the Loess Plateau and then east to its terminus in the Bohai Gulf. In total, the river flows over $5,400 \mathrm{~km}$, passes through nine provinces and autonomous regions and drains an area considerably larger than the area of France. 
The Yellow River Conservancy Commission (YRCC) has the primary responsibility for water management in the Yellow River basin (YRB). This includes flood, sediment, ice, drought, water quality, water allocation and environmental water management. This work is carried out in an integrated way, with one of the key objectives being investing in management actions that jointly improve ecological outcomes and enhance the welfare of the people who live in the basin. YRCC follows an adaptive management model, whereby the actions are based on a continuous review of science-based investigation and monitoring, and an awareness of the changing needs of the communities that live in the basin.

\section{Main issues regarding water resource and environment in the Yellow River basin}

\subsection{Water shortage and the imbalance of water supply and demand}

The growing population, rapid economic development and urbanization in the YRB are intensifying water shortage and environmental degradation. In the last decade, the coal and chemical industries in the autonomous regions of Inner Mongolia, Ningxia and Xinjiang and in Shanxi Province have consumed large amounts of water resources. There were 32 coal and chemical key projects under construction and operation in the National 11th Five-Year Plan (2006-2010) and 15 new key projects are to be initiated in the National 12th Five-Year Plan (2011-2015). These coal and chemical industrial projects will together demand $11.1 \mathrm{bcm}$ of water per year, namely 3.04 million $\mathrm{m}^{3}$ per day, about the same as the water demand for Beijing in 2012 and very much more than current industrial consumption [1]. The total amount of available water resources is relatively inflexible so this additional water requirement can only come by a reduction in the water used by agriculture. The contradiction between the industry and agricultural irrigation and other uses, such as urban demands, environmental conservation, power generation, ice prevention, fisheries, and shipping water gives rise to the greatest challenge of the water quantity management in YRB. There is not enough water available to meet everybody's requirements so all have to make do with less than they would like.

Actually, almost all cities in the YRB face different degrees of water shortages. Although taking into account implementation of strengthened water-saving measures (but excluding water transfer from other river basins), the gap between water resource demand and supply of the Yellow River is estimated to grow to $7.5 \mathrm{bcm}$ in 2020. In order to overcome the shortage of Yellow River water supply, irrational water use occurs, for example over extraction of the groundwater to meet short term needs. In the longer term, irrational water use leads to serious environmental harm and disaster. Statistics show that in 2010 [2], the long-term excessive mining of groundwater formed 4 cones of depression in artesian groundwater and 8 cones of depression in non-artesian groundwater covering a total of 87,777 square kilometers namely $11 \%$ of the YRB. 


\subsection{Soil erosion and water pollution}

The economy of the YRB is based on coal and chemical industries with high water consumption, heavy pollution and low levels of clean production. Large amounts of untreated or ineffectively treated industrial waste water and untreated urban effluent are discharged into the river. In 2010, the effluent discharges into the Yellow River basin streams was 4.4 billion $\mathrm{m}^{3}$, of which civil, industrial and commercial waste water were respectively $1.2,2.9$ and 0.34 billion $\mathrm{m}^{3}$, accounting for $27 \%, 65 \%$ and $8 \%$ of total effluent production. Agricultural runoff is also a significant source of pollution, especially from large scale livestock rearing, contributing about $40 \%$ of COD and ammonia pollution of the river. While The Ministry for Water Resources is responsible for the quality of water in the river and can coordinate basin-wide through YRCC, the Ministry of Environmental Protection is responsible for the control of discharges of pollutants to the river, but must exercise enforcement of standards through the provincial Environmental Protection Bureaus over which it has only partial control to influence municipal governments and industry and even less control over polluting agricultural practices.

\subsection{Flood management}

Most water in the Yellow River originates from the upper reach above Lanzhou, however, more than $90 \%$ of sediment comes from the middle reaches as the river flows through the Loess Plateau region from Hekou Town to Tongguan. Floods carry large amounts of sediment into the downstream river. Since the downstream lacks sufficient water to transport this sediment, most of it is deposited in the river bed, making the Yellow River a hanging river above the surrounding country. This situation generates great flood control risks. As the downstream flood plain of Yellow River stretches to the Huai River and Hai River basins, the Yellow River flood control issues, particularly in the lower reach, has become the country's most serious concern since it relates not only to the water and grain security but the very survival of people and cities in the Yellow River flood risk areas of the North China Plain.

Flood control dams and strengthened dykes have, in recent years, protected against the devastating floods in the Yellow River plain but the economic and human losses caused by flood disasters along the river are still huge. For example, the flood in July to August of 2012 in Gansu Province affected 29.6 million people living in 9 cities and 31 counties. In this flood 2.8 million people were temporarily relocated and more than 1 million people were given emergency living assistance, 300 houses collapsed and 6,000 houses were damaged to various degrees; besides, 20.8 thousand hectares of crops were affected. In total, the direct economic losses amounted to about 620 million RMB Yuan [3]. 


\section{The legal framework of YRB water resource management and development of key legal and administrative instruments for river basin management}

\subsection{The implementation of the main legal instruments for water resource management in YRB}

\subsubsection{Allocation plan for available water of YRB}

Since water is the scarcest resource for economic development in the YRB region, the core social and economic issue concerning water resource is how to allocate the limited available water of the Yellow River among various jurisdictional areas or, further, how to coordinate the interested parties in equal and fair use of the water of the Yellow River. Until around 1987, all parties competed in taking water from the Yellow River and in excessive extraction of ground water for their own regional development with no concern for the consequences for impact on flow in downstream reach. This aggressive taking of ground water resulted in ground water levels in Taiyuan and Xi'an and other cities declining rapidly and brought about serious geological and environmental problems such as water depression cones. The first unified Available Water Allocation Program of Yellow River was thus initiated by Yellow River Conservancy Commission and approved by State Council. It was known as The 87 Program as it took effect in 1987. The 87 Program was a milestone for YRCC tasking them to actually implement integrated water allocation schemes in the YRB. Nationwide, The 87 Program was the first integrated river basin water allocation plan for national key rivers and lakes administrated by specialized river basin management institutions under the Ministry of Water Resources. The aim of The 87 Program was to balance water supply and demand and to solve contradictions and disputes in water use among various jurisdictions in YRB.

While implementation of The 87 Program had strengthened the water management of YRB and alleviated some contradictions between supply and demand of water resources, it did not solve water sharing issues in the Yellow River nor prevent competition for Yellow River water by concerned parties. Considering the conditions of Yellow River water supply and demand had changed, and in particular increasing concern for water required for ecological and environmental functions of the Yellow River, the National Planning Committee and Ministry of Water Resource formed and implemented a new unified available water allocation plan in 1998 - the Program of Yellow River on Annual Allocation of Available Water and Quantity Dispatch of Mainstream Water hereafter called The 1998 Program). The practices of The 1998 Program and WRMB were formally recognized by the revision of the 1988 Water Law in 2002, From then on the 2002 Water Law has provided the legal basis for river basin management institutions (e.g. YRCC) and authorizes them with the power for unified and comprehensive water resources management and river basin water quantity dispatch. 


\subsubsection{Pilot practice of water rights transfer}

A water right transfer pilot in the YRB arose from a sincere concern over poor water efficiency, unreasonable water structure in the YRB and the reality of the water consumption of some provinces and regions of the YRB. The allocated quotas are regularly exceeded and defined indicators concerning river flows are violated. The introduction of a water right transfer system is expected to help ease the existing problems in the function of a marketing mechanism in the Yellow River. In 2003, the YRCC initiated the water right transfer pilot which allowed a province or autonomous region in the YRB to transfer saved water rights on the premise that overall it continued to consume water in compliance with the water quota and indicators defined by the State Council.

The pilot practice of water right transfer first took place in two autonomous regions of Ningxia and Inner Mongolia, guided by the Instructive Opinions of the Ministry of Water Resources on Water Right Transfer Pilot Work in Ningxia and Inner Mongolia (2004). The water administrative departments of the autonomous regional governments, in conjunction with the development and planning committees, formulated overall plans for the water rights transfers which were approved by the YRCC. The YRCC identified 5 water right transfer pilots in Inner Mongolia and Ningxia. The two water right transfer pilot projects in Ningxia were water-saving projects in Qingtongxia Hedong Irrigation Area and in Huinong Canal Irrigation Area, Hexi Corridor. The water saved from these two projects was transferred to the third phase expansion project of Ningxia Dam and Power Plant and the Ningdong Maliantai Power Plant [4]. Compensation of transferred water resources or water rights is a key aspect of the process of water rights transfer. It ought to reflect the value of water resource in a market-oriented base. The water right transfer price in the pilot was calculated as the product of total cost of water rights transfer per unit of water quantity, the period of water rights transfer and the transferred water quantity. Nevertheless the actual total cost of water rights transfer should include - in theory, but have not yet covered in reality - water right conversion costs and reasonable profits, in which the cost of engineering construction and operation, the amount of ecological compensation, the water right conversion period and other factors to be taken into account. Up to the end of 2008, the YRCC had approved 526 water rights transfer projects transferring a total of 228 million cubic meters water. The total investment of the related water-saving projects was 1.226 billion Yuan [5].

\subsection{Recent national policy developments and reform}

In January, 2011, the State Council issued their No. 1 policy document on Water Resources Reform and Development This sets out a 10-year programme of reform and investment in water resources and flood protection infrastructure and well as water resources pricing reform and institutional reform. Since 2011 implementation directives and regulations have been prepared and issued periodically and the principles of the No. 1 water policy document have been incorporated at national, provincial and local levels. 
The major policy and institutional reform introduced in the No. 1 policy document is the introduction of river basin management based on the "three red lines' which are:

- The first red line for water allocation sets water quantity objectives in rivers, lakes and groundwater. It requires the total quantity control of water abstraction.

- The second red line for water use efficiency sets objectives for water use efficiency. This will accelerate the development of national standards regarding water use quotas for high water consumption industries and the service industry.

- The third red line for pollution load management sets maximum permissible total pollution loads for Water Functional Zones, which cover the catchments, reaches of rivers and lakes that must meet specific water quality standards.

For each of these red lines, targets and indicators are set at the level of defined sections of rivers (water functional zones). These also match with targets at local, regional, river basin and national levels. Achievement of the targets is incorporated into the official cadre performance assessment process of the relevant Communist Party of China (CPC) organisation's department. It makes individual officials personally responsible for achieving the outcomes in their annual letters of responsibility through quantified key performance indicators. This is a significantly different control mechanism which is available in China and has more influence on the actions of key actors than general legal or administrative incentive systems. Working out exactly how to frame these indicators will be key to successful implementation of national water resources and river basin management policy. The most important indicators in the official cadre assessment have been GDP growth, population control, social stability and employment but environmental factors have recently been introduced with much higher priority than in the past.

\section{The main challenges for sustainable and integrated water resource management of YRB}

\subsection{The integrated institutional system for water resource management}

The institutional mode for the water resource management in the Yellow River basin lies in two independent but interacting systems, one is the regional administrative system where provinces or autonomous regions in YRB play roles for water resource management within particular jurisdictional regions; the other is the river basin management system where YRCC, as the river basin management institution, has the role for the integrated water resource management for the entire river basin. YRCC is administrated by the Ministry of Water Resources like all other institutions for national key rivers or lakes. In the power hierarchy, provincial governments are at the same level of administrative power as the Ministry of Water Resources, in that they are each ultimately responsible to the State Council; in this hierarchy the YRCC is at a lower level than provincial governments in the YRB. Therefore the common understanding 
of the most serious challenge in institutional integrated management of YRB is the difficulty to achieve institutional coordination and cooperation in water resources management among the provincial (and lower level) administrative authorities for water resources [6].

The revision of Water Law in 2002 intended to provide a clear institutional status for river basins management institutions and in particular for national key rivers like the Yellow River. The law, mainly Articles 12 and 15 of Water Law 2002, state that the combined system of the regional management and river basin management is the general institutional arrangement to be applied in water resources management, in which the river basin management had a higher legal status than regional water resources management. According to the Water Law 2002, the main tools for the river basin management include the preparation of river basin planning, approval of the water pollutant carrying capacity, water quality monitoring, setting limits on sewage outfalls, formulating water allocation and water regulation plans and the implementing of defined integrated water regulatory tools, for example issuing water taking permits. By law, these integrated management tools serve as the foundations for the regional water resources management in the YRB provinces.

With regard to water quality management and pollution load control, YRCC Water Resources Protection Bureau (WRPB) has responsibility for calculating the carrying capacity and pollution load allocations for each water functional zone but they only have authority to issue control quotas, permits and conduct monitoring in the river stream and at the point where any sewer, ditch or tributary enters the main river or YRCC controlled main tributary. There is no linked permitting system connecting water taking and water discharging and it is not possible for YRCC to get directly involved in controlling the pollution discharges from industry because that is the responsibility of the local environmental protection bureaus. The WRPB is nominally a joint agency with the Ministry of Environmental Protection, but in practice this link is very weak and does not afford integrated management of polluting discharges. Significant reform of the discharge permitting regime is required to put in place effective mechanisms for coordinated management.

\subsection{The efforts and dilemma of the "Yellow River Law"}

It has been the ongoing topic for a decade to initiate an integrated special law for YRB, the Yellow River Law. The intent of this law is to not only follow the general principles of the Water Law, but also reflect the characteristics of the Yellow River so that the healthy and orderly management of the Yellow River could be carried out. As early as in 2001, the Asian Development Bank (ADB) provided China with a technical assistance (TA) to explore the feasibility of formulation of the Yellow River Law. One output of this ADB TA was to provide an expert draft of Yellow River Law. The opposing views to creating a special Yellow River Law assert that the specific legislation of the Yellow River could result in inconformity with existing basic legal principles and institutional systems of the river basin management. The existing laws and regulations of the State Council dealing with water pollution control and water resources utilization 
should be sufficient for YRB water resource management. The problems of YRB water resource management are not a lack of legislation but ineffective implementation of the existing relevant laws and regulations for Yellow River management.

However, the supporting views for a special law for YRB are: (i) the current water law system is difficult to adapt to special needs of the Yellow River; Water Law 2002 and other water related laws were quite inadequate to implement integrated river basin management. (ii) The long history and rich experience of YRCC excising river basin management can provide valuable lessons for formulating the Yellow River Law [7]. (iii) From the example of foreign legal practice of river basin management, for example, the Tennessee Valley Authority Act (United States), Colorado River Administration Law (United States), Murray-Darling River Agreement (Australia) and Waikato River Basin Administration Law (New Zealand), a specialized river basin law could consolidate and facilitate the legal status of the river basin institutions and more successfully integrate management. (iv) In 2011, the formulation and taking effect of Administrative Regulations for Taihu Lake Basin created a comprehensive legislative precedence in the field of national key rivers or lakes in China.

The dilemma of the Yellow River Law demonstrates that legislation is the systematic action of the society and restricted by many social, economic and political factors. Indeed, whether the formulation of Yellow River Law is put into practice or not still requires exploration and discussion, and the establishment of effective integrated management in the Yellow River basin in order to deal with water allocation and water pollution, and water and soil conservation will be the consensus of the interested parties in the society.

\section{Conclusions}

The Yellow River is an exceptional river, despite only moderate flows from its vast but arid catchment it carries the greatest sediment load of any river on earth. This makes it especially challenging to manage and potentially deadly, representing the world's greatest risk of loss of life to a natural disaster should a major flooding incident occur. The 2011 No 1 policy document for water sector reform and subsequent supporting regulations goes some way to achieve this. The "3 red lines" principle produces a framework for water quantity management, water savings incentives and water quality protection and this is set in the context of a greatly increased 10-year water investment programme. More work is still required to define the mechanisms for implementation such as enhanced water abstraction and discharge permitting systems, comprehensive monitoring and data management, standards and objectives based on environmental outcomes and the economic and market based management of water. This policy document also sets out the uniquely Chinese approach to implementation through the national system of key performance indicators for senior officials assessment that now includes environmental and water resources 
outcomes and standards compliance amongst the factors determining their pay and career progression.

The critical challenges in the Yellow River basin still remain as how to implement these systems across the river basin both vertically and horizontally and to codify this in the systems of policy directives, laws, regulations and standards at national and local levels to make YRB a better living place for the people.

\section{Acknowledgements}

This study is financially supported by the Special Fund of International Science and Technology Cooperation (2014DFA71910); National Natural Science Foundation of China (51409014) and Special Fund for the Public Interest of the Ministry of Water Resource (201201067-1).

\section{References}

[1] Wen Yu-jiao. The century journey for China's environmental protection water flows upwards: the implementation of the most stringent water resources management system, China Environmental Newspaper, July 10, 2012, p. 6.

[2] YRCC. 2010a. The 2010 Bulletin of Yellow River Basin.

[3] Peng Xiang and Hu He-ping. Evaluation on allocation system of available water of the Yellow River, Journal of Yellow River, 2006 (4), p. 41.

[4] Cai Ximing and Yang Yi-Chen. Water Allocation Management in the Yellow River Basin: Potential for Water Trading? Yellow River Basin: Living with Water Scarcity. Publisher: International Food Policy Research Institute (IFPRI), 2010, p. 689.

[5] Wang Yahua and Tian Fuqiang. Evaluation and prospect on the pilot program of water right transfer in the Yellow River Basin, the Journal of China Water Resources, 2010 (1), p. 21.

[6] $\mathrm{Xu}$ Lin. Problems and Countermeasures of Water Administrative Law Enforcement in the Upper and Middle Reaches of the Yellow River Basin, the Journal of People's Yellow River, 2013 (7), p. 16.

[7] Zhang Jian-wei and Wang Yan-ling. Some legal issues on Drafting the Yellow River Law, the proceedings of the 2008 national symposium of environmental and resources law: the legal studies on sustainable utilization of water resources and water environment protection, the Research Institute of Environmental Law, Wuhan University, 2008, p. 471. 